\title{
MACRO- AND MICROMORPHOLOGY OF THE LEAF, STEM, STEM BARK AND FLOWER OF VANGUERIA EDULIS CULTIVATED IN EGYPT
}

\author{
D. W. Bishay, E. Y. Backheet, Y. G. Gouda and S. M. Moustafa
}

Department of Pharmacognosy, Faculty of Pharmacy, Assiut University, Assiut, Egypt

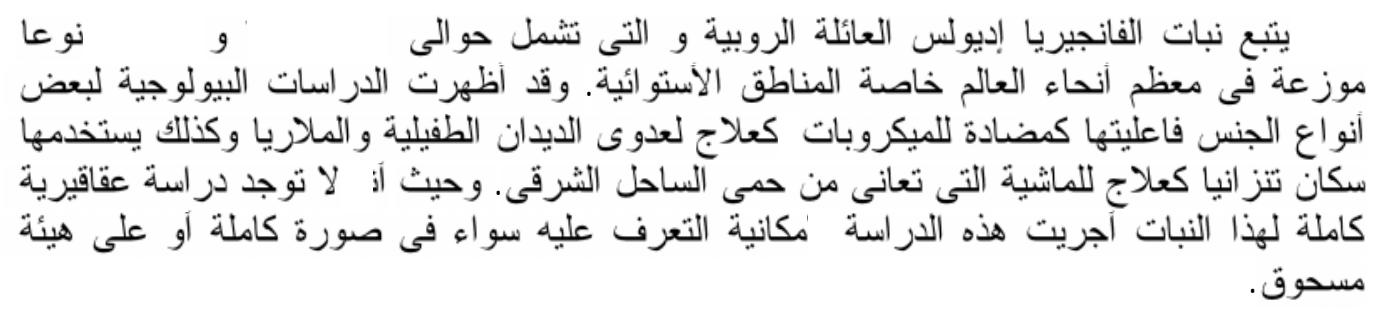

Vangueria edulis belongs to Rubiaceae which includes about 620 genera with almost 13000 species which is widely distributed but mainly tropical. Biological studies showed that some species of the genus Vangueria showed antimicrobial activity, reported to have anthelmintic action and antiplasmodial activity and fed to cattle suffering from East Coast Fever. No detailed information could be traced concerning the macro- and micromorphology of the plant. This provoked the authors to carry out this study to identify the drug in both entire and powdered forms.

\section{INTRODUCTION}

Rubiaceae (The madder family) is a large plant family exhibiting a wide range of habit, including trees, shrubs and herbs. It includes about 620 genera with almost 13000 species which is widely distributed but mainly tropical $^{1 \& 2}$. The rubiaceaous plants are of economic importance primarily for several tropical crops, notably Coffea, Cinchona and Cephaelis. In addition to these, a number of ornamentals are grown including Gardenia, Rubia, Mitchella, Galium, Ixora and Vangueria ${ }^{3}$.

The tribe Vanguerieae are morphologically homogeneous and characterised by a number of common features which clearly define the tribe from other Rubiaceae, such as the axillary paired inflorescences; a valvate aestivation; secondary pollen presentation, one pendulous ovule per locule, pyrenes with an apical germination slit and soft oily endosperm with very large embryos ${ }^{4}$.

Vangueria infusta showed antibacterial and antifungal activities, also it was reported to fed to cattle suffering from East Coast
Fever ${ }^{5}$. In folk medicine, it is used as a cure for parasitic worm infections in the form of a decoction and also it was reported to have anthelmintic and antiplasmodial activities ${ }^{5}$.

\section{HABITAT}

Vangueria edulis (Vahl) Vahl Variety: bainesii Heirn (Fig. 1) is a shrub or a small tree, perennial, not exceed 6 meters in length and known as spanish tamarind ${ }^{6}$.

\section{MATERIAL}

Fresh samples of $V$. edulis including (leaves, stem, stem bark and inflorescence) were collected from El-Zohria research garden, Cairo, Egypt (flowering stage May 2008) and were kindly identified by Prof. Dr. Mo'men Mostafa Mahmoud, Professor of Taxonomy, Faculty of Science, Assiut University. Different organ samples were preserved in a mixture of alcohol (70\%)-glycerin-water (1:1:1) and stored in a tightly closed containers. Another samples were separately air-dried and reduced to fine powder. 


\section{1- The leaf}

A- Macromolphology (Fig. 2A and 2B)

The leaves are shortly petiolated, simple, very large, glabrous, elliptic-ovate in shape, with acuminate apices, entire margins and pinnate reticulate venation. They are in an opposite decussate arrangement. Stipules are connate and interpetiolar. The leaf measures $(10-12 \mathrm{~cm})$ in length and $(3-3.5 \mathrm{~cm})$ in width (at the middle portion). The upper surface of the leaf has dark green colour while the lower one is paler. The petiole is nearly cylindrical to subcylindrical, green in colour measuring (0.2$0.3 \mathrm{~cm})$ in length and about $(0.2 \mathrm{~cm})$ in diameter. The dried leaves are tasteless having faint odour.

\section{B- Micromorphology}

The transverse section through the midrib region (Fig. 3A and 3B), appears more or less bi-convex in outline, exhibiting a large median main vascular strand; isolated bundles of pericyclic fibres and parenchyma cells.

The leaf is dorsiventral in structure. The mesophyll is differentiated into an upper palisade which is interrupted in the midrib region by (1-2) rows of chlorenchyma followed by a mass of chollenchyma cells and spongy tissue. A larger lower mass of collenchyma cells is present. Numerous clusters of calcium oxalate as well as starch granules are scattered in the mesophyll and the cortical tissue.

\section{The upper epidermis}

The upper epidermis (Fig. 4) is formed of a row of isodiamtric to subrectagular cells measuring (35-37-39 ) in height covered with thick cuticle; they are polygonal having straight anticlinal walls and covered with smooth cuticle (Fig. 5A and 5B). The cells measure (37-40-43 ) in length, (17-21-25 ) in width. They are glabrous, free from stomata showing non lignified sclerenchymatous cells, a character reported in some genera of the family ${ }^{1}$.

\section{The lower epidermis}

The lower epidermis (Fig. 4) consists of a row of isodiametric to subrectangular cells measuring (10-12-16 ) in height; they are polygonal with slightly sinuous anticlinal walls, covered with smooth cuticle and measure (39-51-57 ) in length and (6-15-24 ) in width (Fig. 5C and 5D). Hairs are absent while paracytic stomata are present. Superficial non lignified sclerenchymatous cells are also found but to a lesser extend compared to the upper epidermis.

\section{The neural epidermal cells}

The neural epidermal cells (Fig. 6) consists of a row of isodiametric to subrectangular cells measuring (22-23-24 ) in height; they are polygonal, axially elongated with straight anticlinal walls and measuring (55-59-64) in length and (12-16-18) in width (Fig. 5E and 5F). Superficial network of sclerenchymatous cells are present between cells.

\section{The mesophyll (Fig. 4)}

The leaf is dorsiventral consists of (3-4) rows of columnar palisade cells, the first two rows are longer than the last ones and measure (40-44-48 ) in length and (8- $\underline{10-12})$ in width while those of the last two rows measure (2326-28 ) in length and (11- $13-15$ ) in width. The spongy tissue is formed of thin walled, polygonal to rounded parenchymatous cells with wide intercellular spaces containing chloroplasts, cluster crystals of calcium oxalate measuring (17-19-22 ) in diameter in addition to oval, almost compound starch granules with indistinct hilum or striation, measuring (3-4-4-5 ) in diameter.

\section{The cortical tissue (Fig. 6)}

The cortical tissue is represented by (2-3) rows of rounded chlorenchymatous cells measuring (20-22-27 ) in diameter followed by a mass of collenchymatous cells, formed of (3-7) rows of nearly rounded, scanty, cellulosic cells with no intercellular spaces, measuring $(11-\underline{14}-18)$ in diameter followed by parenchyma cells of about (6-8) rows, measuring (16-18-24 ) in diameter. Some of the parenchyma cells contain starch granules as well as clusters of calcium oxalate similar to that of the mesophyll. The endodermis is formed of thin walled parenchyma cells containing starch granules. 


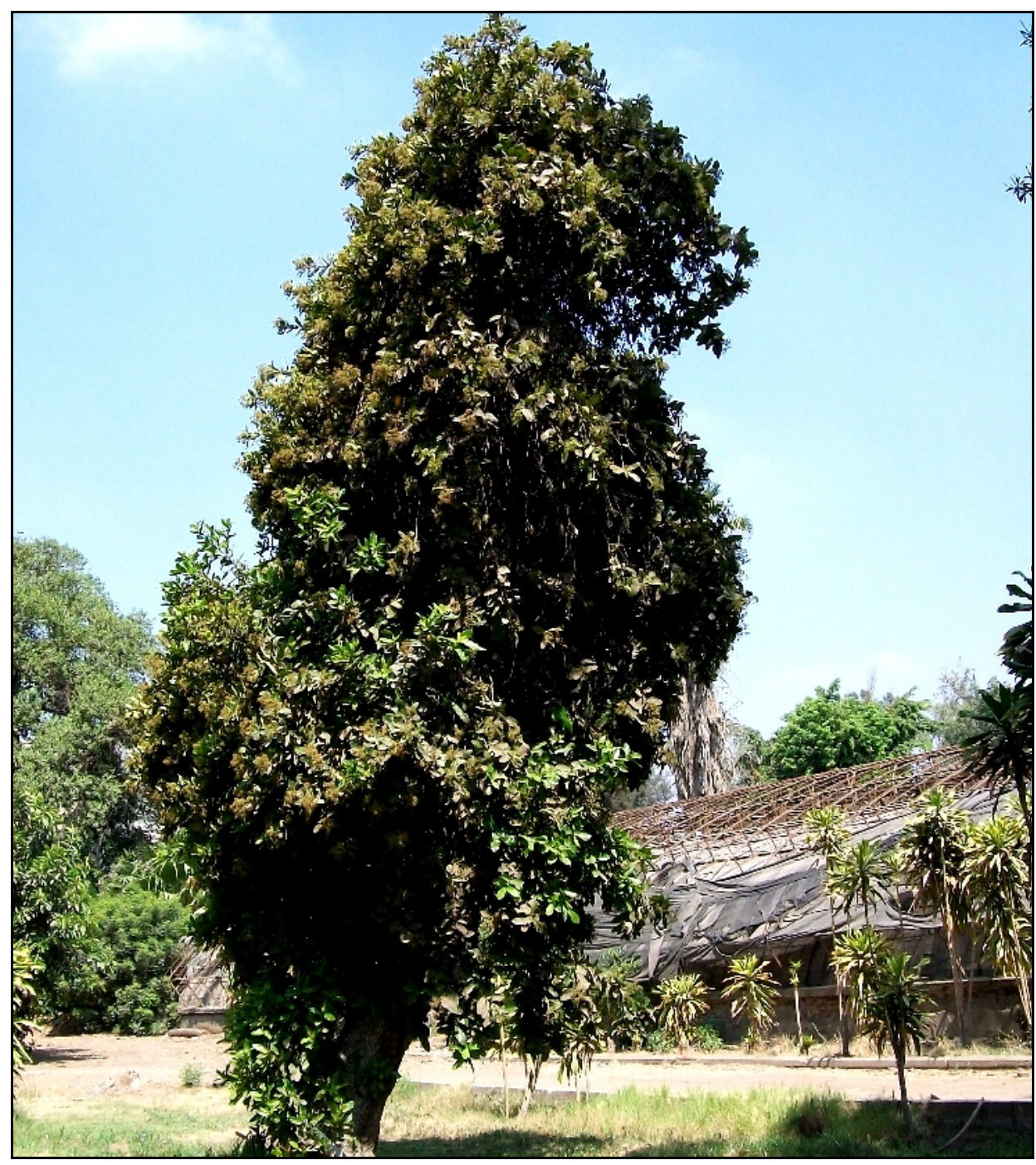

Fig. 1: Photo of the plant

$\mathrm{x} 0.02$ 


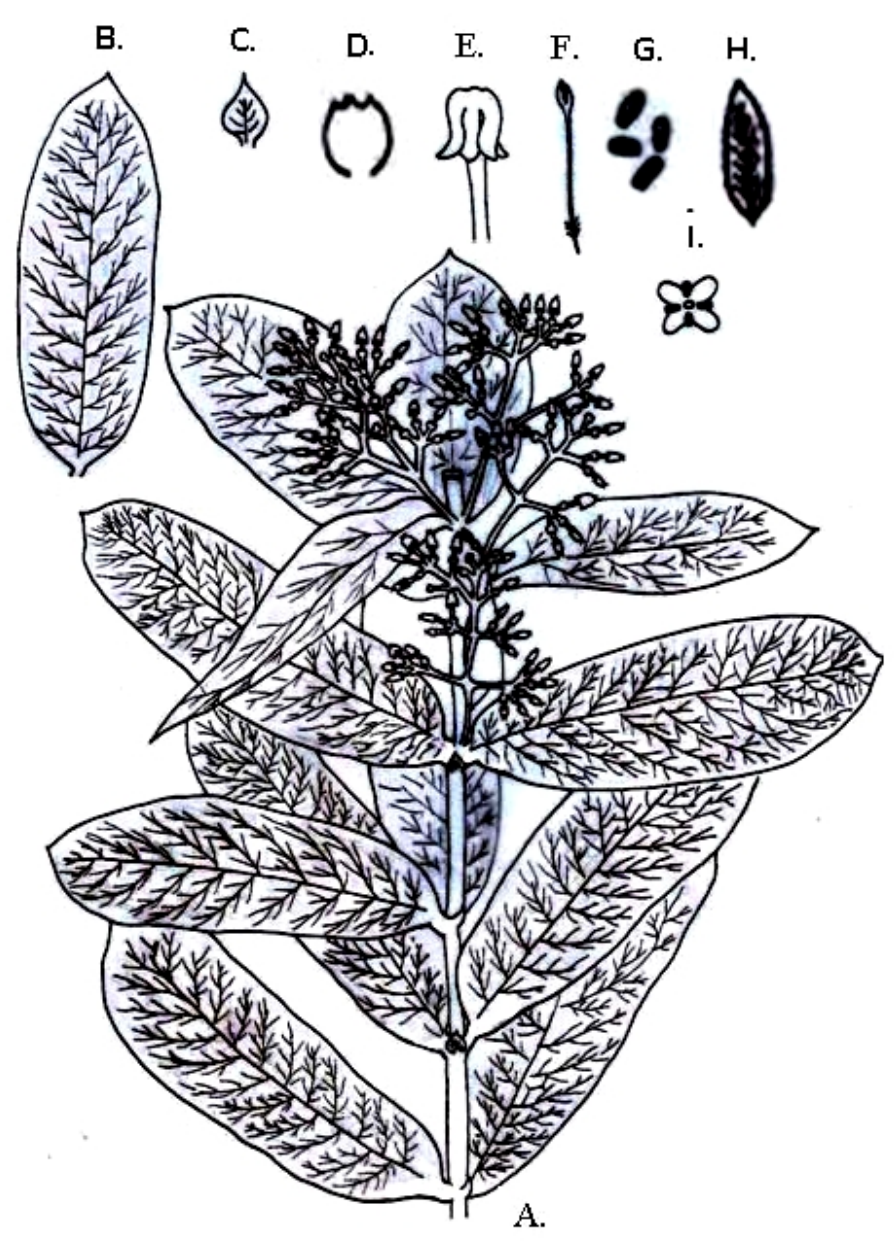

Fig. 2: Macromorphology of the leaf, stem and inflorescence.
A. Morphology of the aerial part
$(\times 0.5)$
B. Morphology of the leaf
$(\times 0.5)$
C. Morphology of stipules
$(\times 0.5)$
D. Morphology of the calyx
$(\times 6)$
E. Morphology of the corolla
$(\times 3)$
F. Morphology of the stigma and style
$(\times 3)$
G. Morphology of the anther
$(\times 5)$
H. Morphology of the bracteole
$(\times 5)$
I. Corolla and stamens seen from above
$(\times 3)$ 


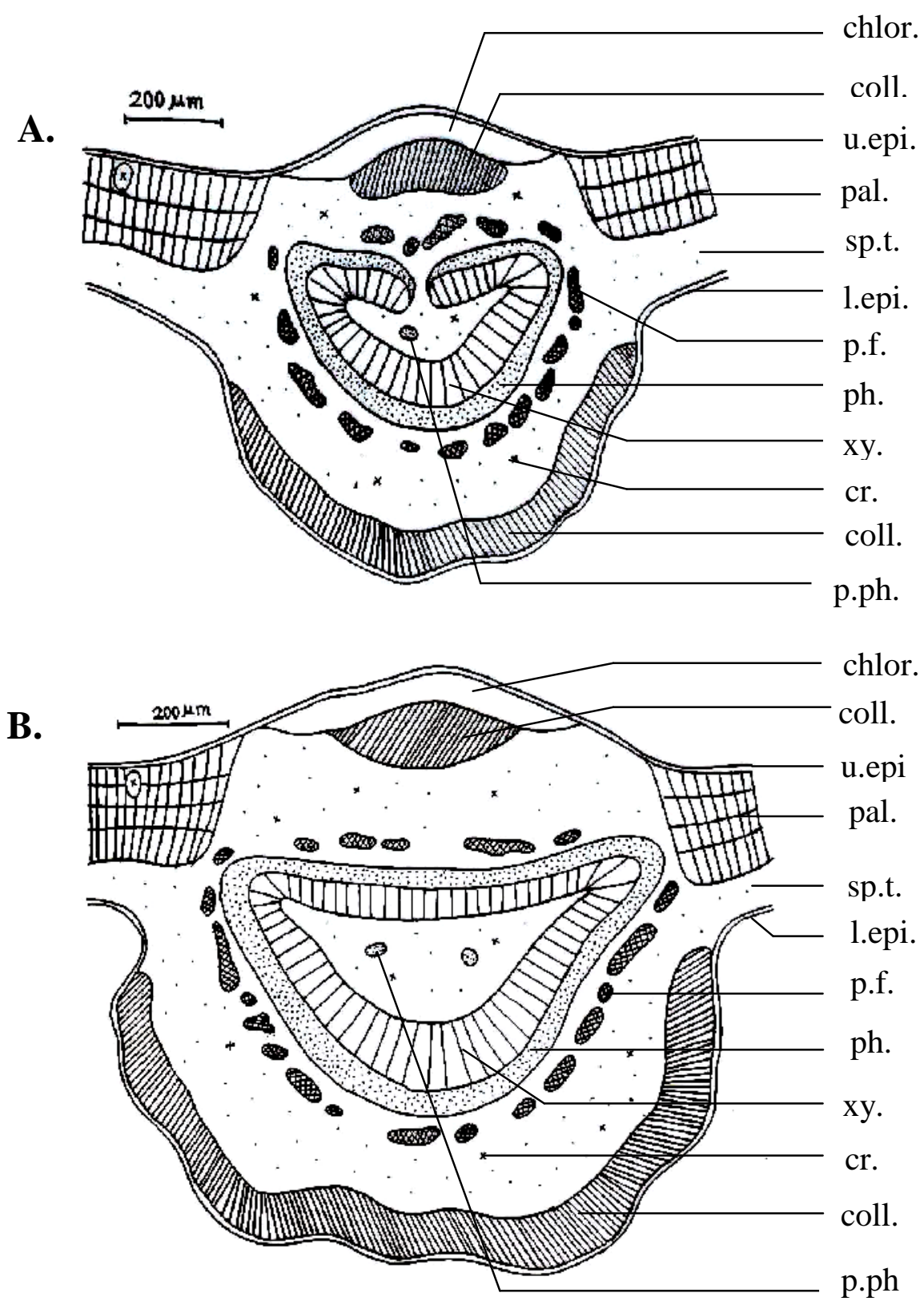

Fig. 3: The diagrammatic T.S. in the leaf.

A: In the middle part of the lamina.

B: Near the basal part of the lamina.

chlor., chlorenchyma; coll., collenchyma; cr., cluster of calcium oxalate; 1.epi., lower epidermis; p.f., pericyclic fibres; p.ph., perimedullary phloem; pal., palisade cells; ph., phloem; sp.t., spongy tissue; u.epi., upper epidermis; xy., xylem. 


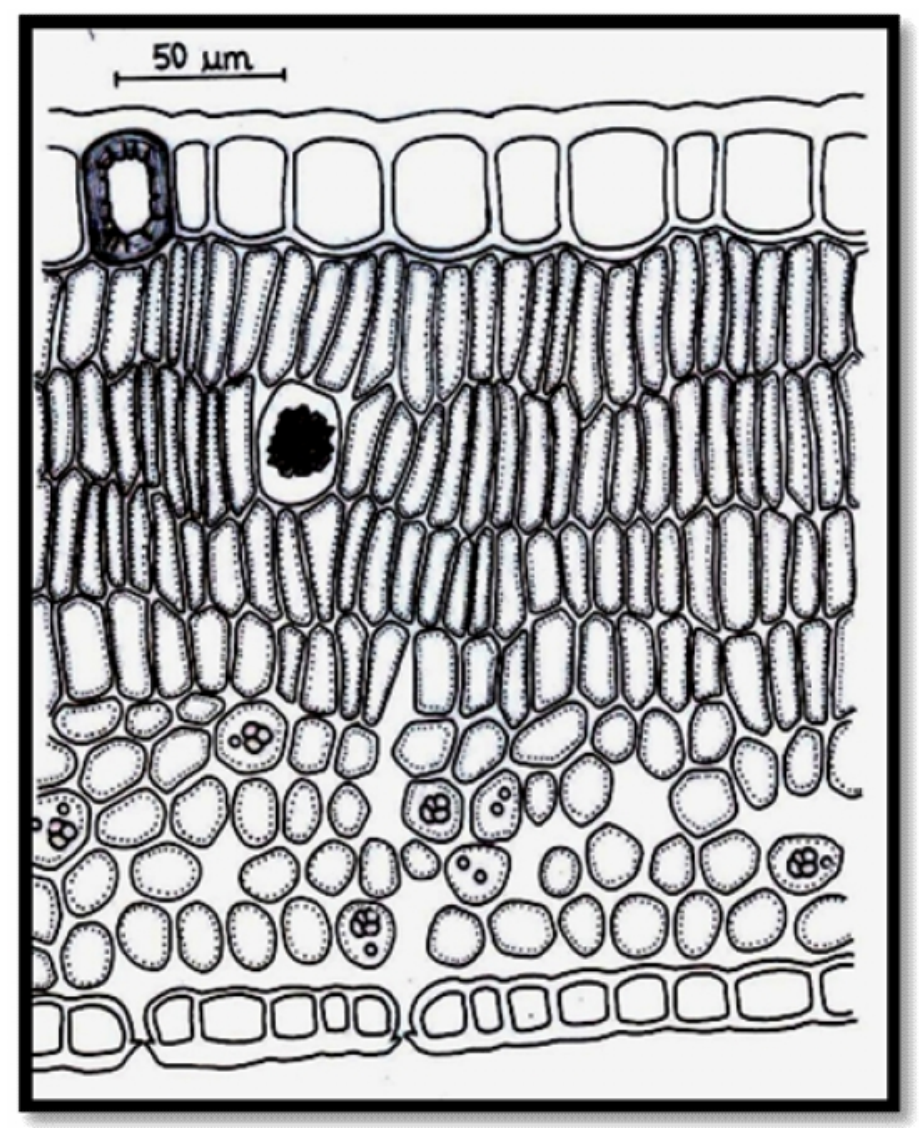

Fig. 4: The detailed T.S. in the lamina.

cr., cluster of calcium oxalate; cu., cuticle; l.epi., lower epidermis; pal., palisade cells; scl., sclerenchyma; sp.t., spongy tissue; st., starch; u.epi., upper epidermis. 


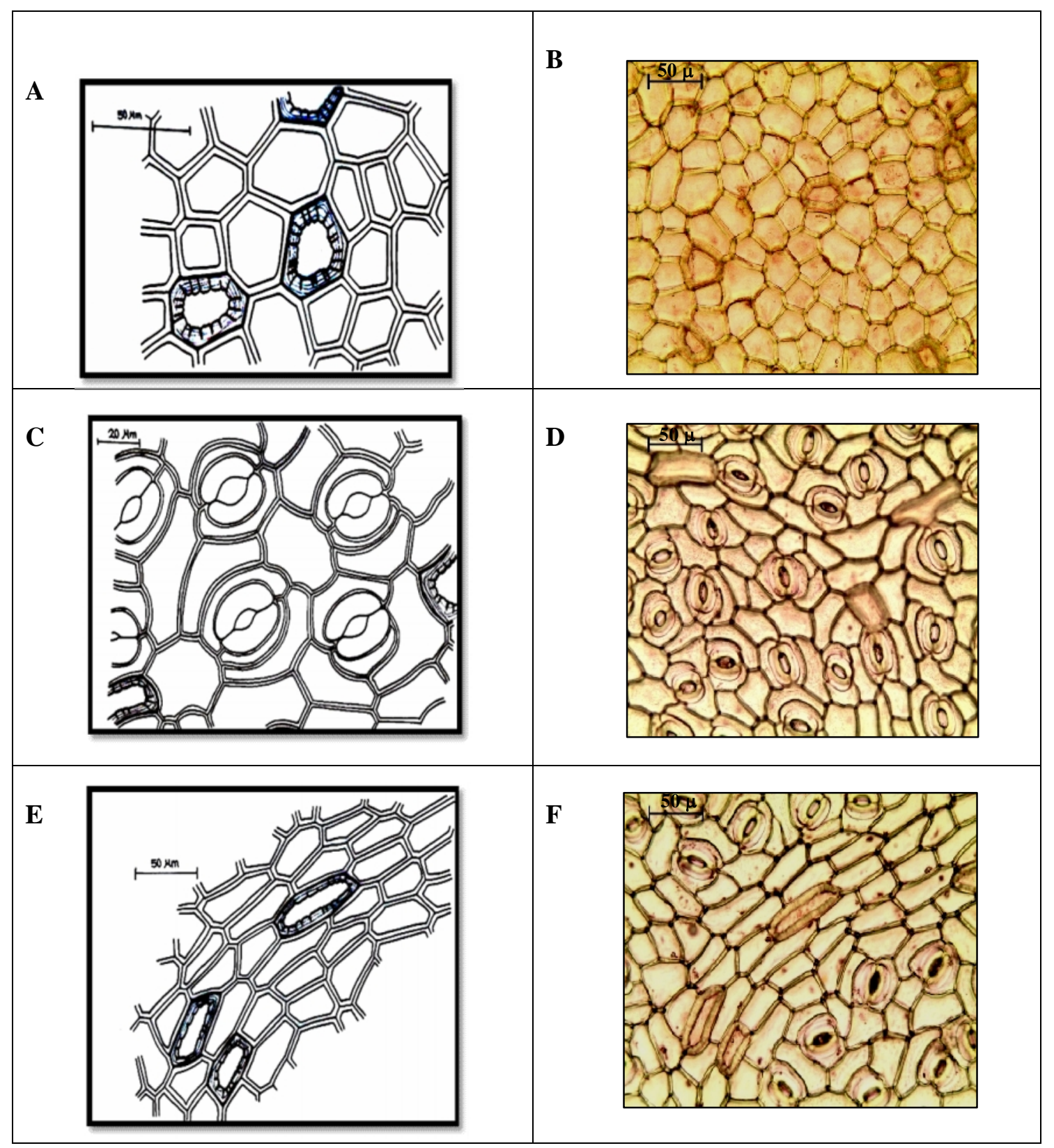

Fig. 5: The surface preparation and photos of:

A and B: The upper epidermis of the leaf.

$\mathrm{C}$ and D: The lower epidermis of the leaf.

$\mathrm{E}$ and F: The neural epidermal cells of the leaf.

scl., sclerenchyma; st., stomata. 

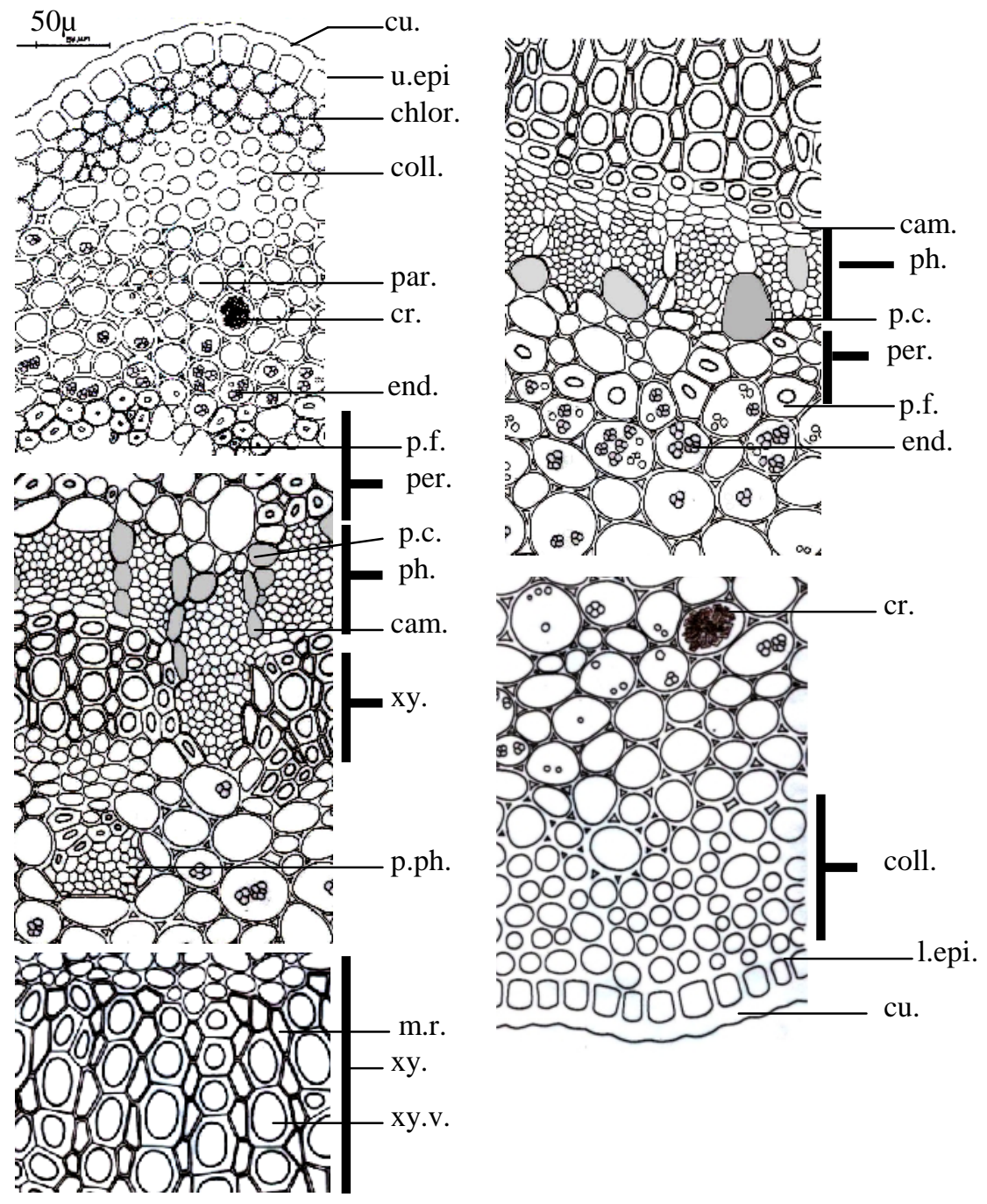

Fig. 6: The detailed T.S. in the midrib region in the middle part.

cam., cambium; chlor., chlorenchyma; coll., collenchyma; cr., cluster of calcium oxalate; cu., cuticle; end., endodermis; l.epi., lower epidermis; m.r., medullary rays; p.c., pigment cell; p.f., pericyclic fibres; p.ph., perimedullary phloem; par., parenchyma; per., pericycle; ph., phloem; u.epi., upper epidermis; xy., xylem; xy.v., xylem vessel.

\section{The vascular system}

Deeply crescentic, with one contineous or two zones of horizontal additional inverted strand from the ends of the crescent interrupted in the center by parenchyma cells (Fig. 3A and 3B).

The pericycle is nearly continuous ring of fibers interrupted by few parenchyma cells. These fibres are of moderately thick, slightly lignified walls and narrow lumina. They measure (13-14-17 ) in diameter.

The phloem is formed of cellulosic elements mainly, sieve tubes, companion cells and phloem parenchyma including scattered large pigmented cells. The phloem fibres are absent.
The cambium is formed of (1-2) row of thinwalled, subrectangular, tangentially elongated cellulosic cells.

The xylem consists of radial rows of lignified vessels; measuring (18-26-32 ) in diameter traversed by lignified uni- to bi-seriate rectangular medullary rays and rectangular to subrectangular wood parenchyma with lignified walls and wide lumina.There are patches of "perimedullary or intraxyllary phloem" in the concavity of the crescent vascular bundle accompanied by lignified fibres. 


\section{The petiole}

The petiole is usually shield-shaped and commonly with more or less well-developed wings; exhibiting a large median vascular strand, usually accompanied by smaller accessory (2-3 bundles) toward the wings. The main vascular strand is crescent-shaped, curved inward with few small accessory strands in the concavity. There are scattered single or groups of heavily lignified sclereids in the lower part. Abundant clusters of calcium oxalate and starch granules are observed in the cortical region (Fig. 7).

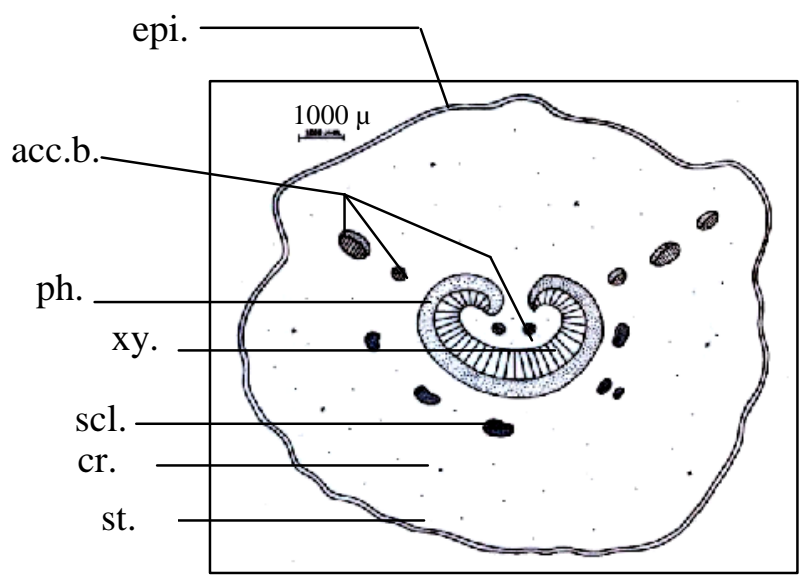

Fig. 7: The diagrammatic T.S. in the petiole.

acc.b., accessory bundles; cr., cluster of calcium oxalate; epi., epidermis; ph., phloem; scl., sclereids; st., starch; xy., xylem.

\section{The epidermis}

The epidermis (Fig. 8) is formed of one row of isodiametric to subrectangular cells containing brown pigments measuring (22-2528 ) in height and covered with thick cuticle; they appear polygonal, usually elongated with straight anticlinal walls, measuring (29-31-36 ) in length and (9-11-15 ) in width and covered with smooth cuticle (Fig. 9). No stomata were observed.

\section{The cortical tissue}

It is formed of (20-25) rows of parenchyma cells with wide intercellular spaces (Fig. 8). They are usually rounded increasing gradually in size towards the inside and containing clusters of calcium oxalate measuring (29-31-32 ) in diameter and starch granules which are mainly simple, circular with indistinct hilum and striations measuring (1-2
) in diameter. Heavily lignified, large pitted sclereids with narrow or wide lumina are present under the vascular bundle. The endodermis is formed of thin walled parenchyma cells containing starch granules.

\section{The vascular system (Figs. 7 and 8)}

The vascular system is represented by a main crescent-shaped collateral vascular strand consists of xylem followed by phloem, in addition to smaller accessory bundles either in the cortical tissue towards the wings or in the concavity of the crescent.

The pericycle consists of (2-3) layers of thin walled, non lignified parenchyma cells.

The xylem consists of lignified vessels measuring (16-18-20 ) in diameter, uni- to biseriate polygonal to subrectangular medullary rays with non lignified thin walls.

The phloem consists of sieve tubes, companion cells and phloem parenchyma with scattered large pigmented cells.

\section{The powdered leaf (Fig. 10)}

Grayish green in colour, tasteless with faint odour. It is characterized by the following:

1- Fragments of both upper and lower epidermises which are glabrous and covered with smooth cuticle. The upper epidermal cells are polygonal with straight anticlinal walls including non lignified sclerenchy-matous cells. The lower epidermal cells are polygonal with slightly sinuous anticlinal walls having paracytic stomata.

2- Fragments of polygonal axially elongated neural epidermal cells with straight anticlinal walls showing non-lignified sclerenchymatous cells.

3- Fragments of polygonal, usually elongated epidermal cells of the petiole with straight anticlinal walls covered with smooth cuticle containing brown pigments. No stomata were observed.

4- Palisade and spongy parenchymatous cells, containing chloroplasts and few compound starch granules.

5- Numerous starch granules either oval compound or circular simple with indistinct 
hilum and striations as well as clusters of calcium oxalate.

6- Fragments of pericyclic fibres with moderately thick, slightly lignified walls, narrow lumina and blunt apices.

7- Fragments of lignified xylem vessels mainly of spiral, pitted and scalariform thickenings.

8- Fragments of tracheids and tracheidal vessels with lignified scalariform walls.
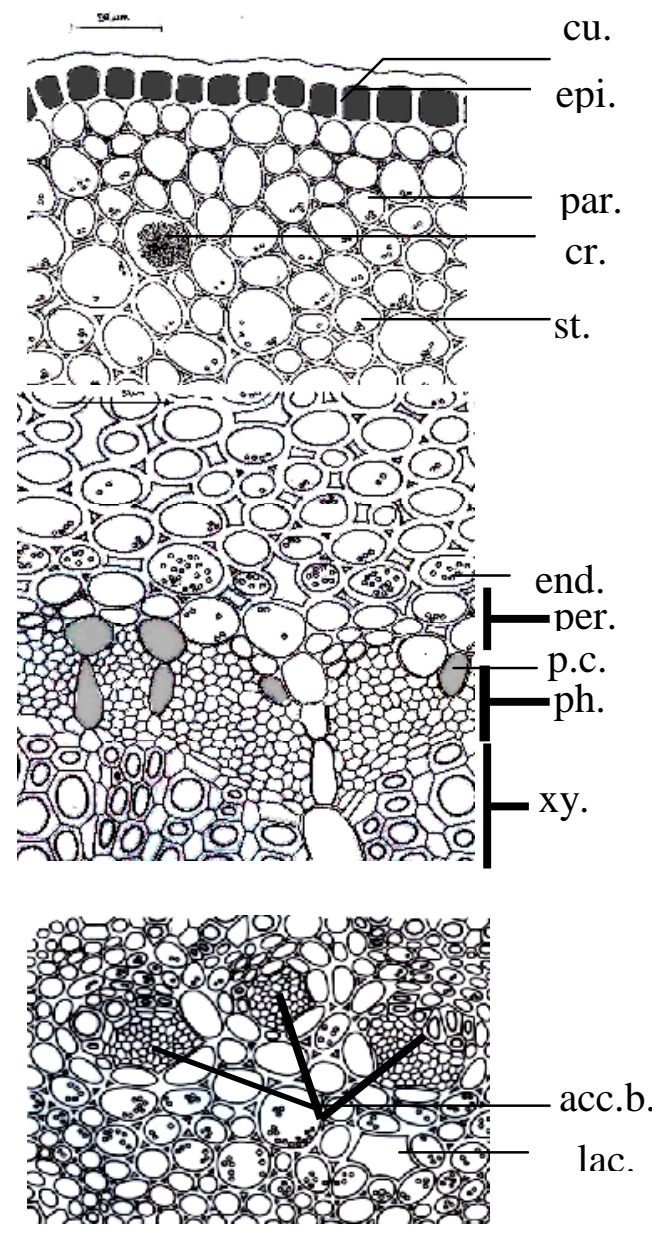

9- Scattered rectangular to subrectangular wood parenchyma with lignified pitted walls.

10- Fragments of polygonal to subrectangular medullary rays.

11- Large sclereids from the petiole which are heavily lignified, pitted with thick walls and narrow or wide lumina.
50

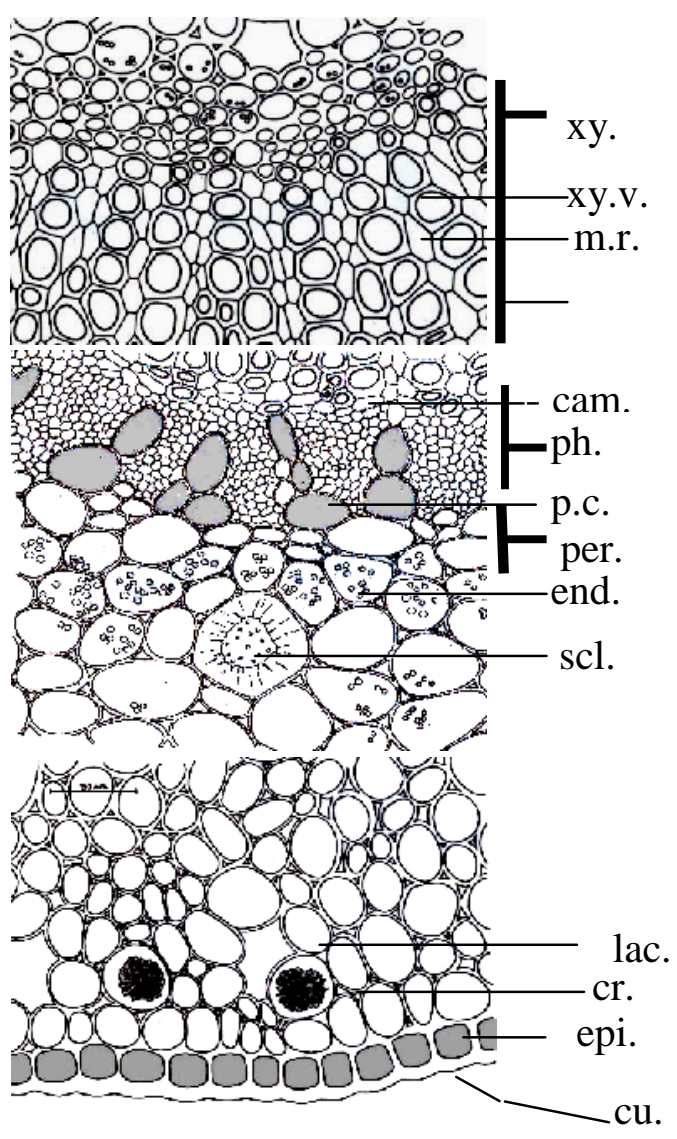

Fig. 8: The detailed T.S. in the petiole.

acc.b., accessory bundles; cam., cambium; cr., cluster of calcium oxalate; cu., cuticle; end., endodermis; epi., epidermis; lac., lacuna; m.r., medullary rays; p.c., pigment cell; par., parenchyma; per., pericycle; ph., phloem; scl., sclereids; st., starch; xy., xylem; xy.v., xylem vessel.

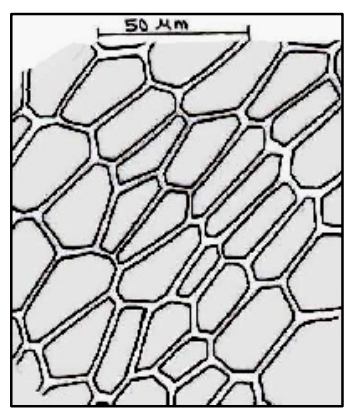

Fig. 9: The epidermis of the petiole. 
u.epi.
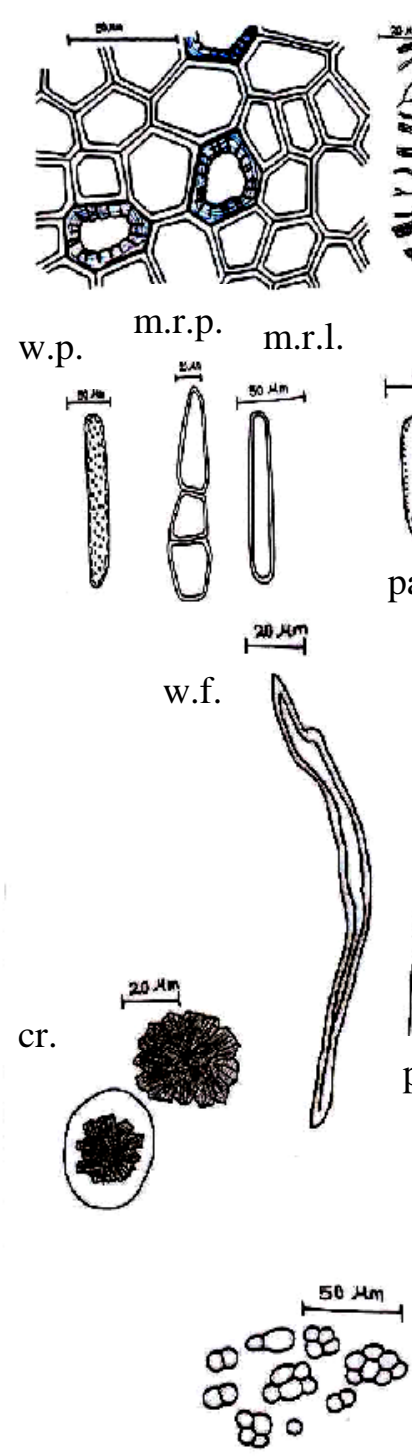

st.1. 1.epi.

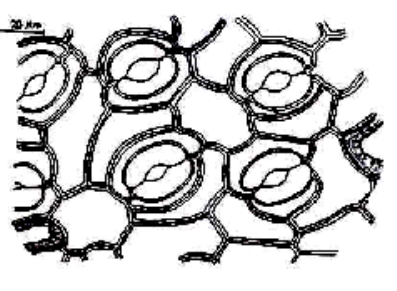

sp.t.
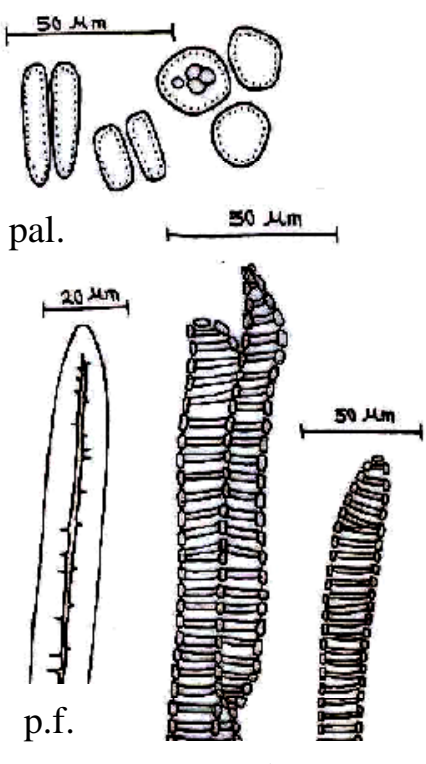

tr. and tr.v.

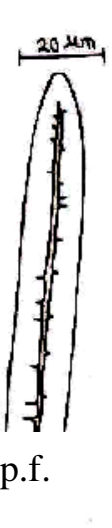

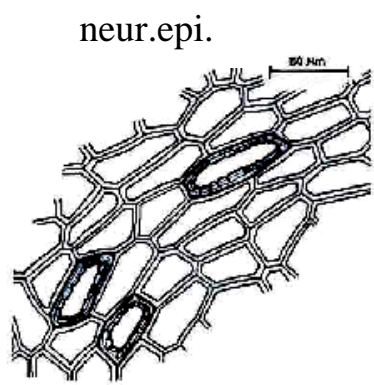

epi.p.
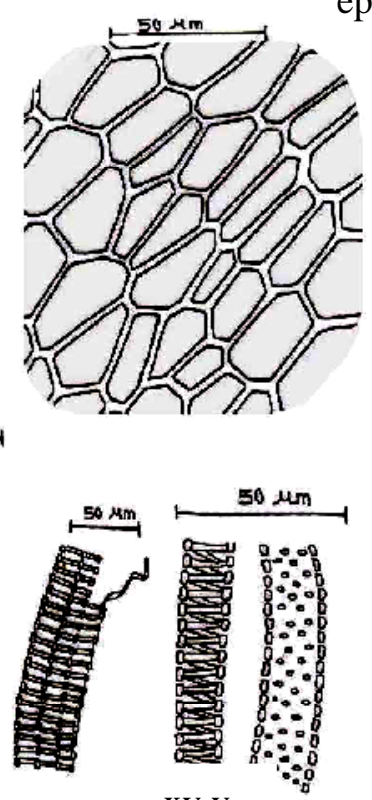

xy.v.
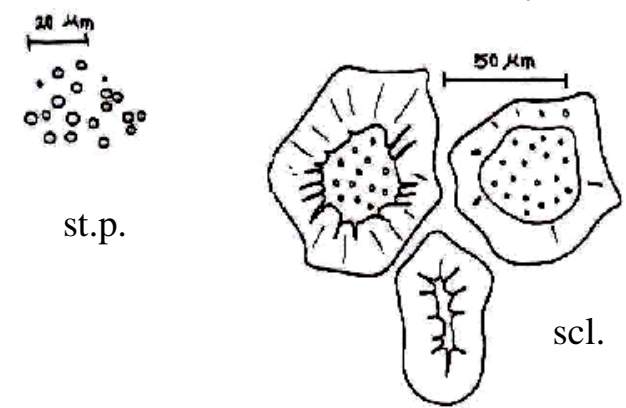

Fig. 10: Elements of the powdered leaf.

cr., clusters of calcium oxalate; epi.p., epidermis of the petiole; l.epi., lower epidermis of the leaf; m.r.l, medullary rays from the leaf; m.r.p., medullary rays from the petiole; neur.epi., neural epidermis; p.f., pericyclic fibres; pal., palisade cells; scl., sclereids; sp.t., spongy tissue; st.l., starch from the leaf; st.p., starch from the petiole; tr. and tr.v., tracheids and tracheidal vessels; u.epi., upper epidermis of the leaf; w.f., wood fibres; w.p., wood parenchyma; xy.v., xylem vessels. 


\section{2- The stem}

\section{A- Macromolphology (Fig. 2A)}

The stem is erect, suffruticose, perennial, rounded in its upper part and oval in the lower one. It is about $(0.3-1 \mathrm{~cm})$ in diameter. It is monopodially branched showing internodes up to $(7 \mathrm{~cm})$ in the lower parts and shorter in the upper ones. The surface of the young shoots is smooth to some extent, green in colour, sometimes with faint purplish tings while that of the older shoots is rough, longitudinally wrinkled and brown in colour. The stem is tastless breaks with fibrous fracture and has faint odour.

\section{B- Micromorphology (Figs. 11 and 12)}

The transverse section (Fig. 11), appears nearly oval in outline and glabrous. It shows an epidermis, narrow cortex formed of parenchyma cells containing clusters of calcium oxalate and starch granules including isolated groups of heavily lignified sclereids. There is a large median collateral vascular bundle enclosing a wide central pith.

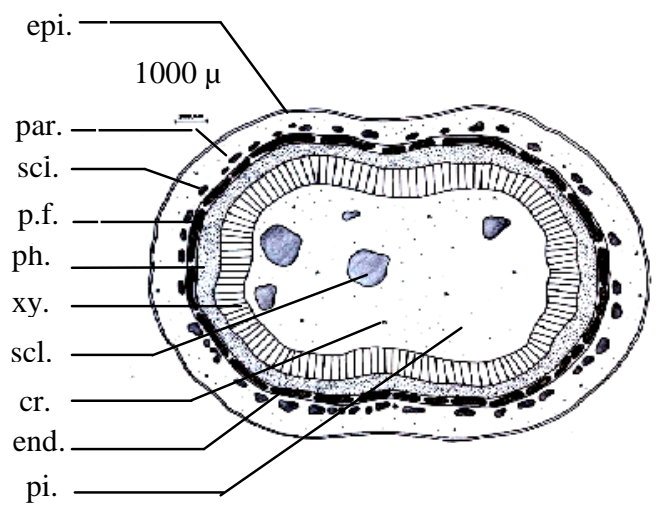

Fig. 11: The diagrammatic T.S. of the young stem. cr., cluster of calcium oxalate; end., endodermis; epi., epidermis; p.f., pericyclic fibres; par., parenchyma; ph., phloem; pi., pith; scl., sclereids; xy., xylem.

\section{The epidermis}

It is formed of square to sub rectangular cells measuring (11-15-17 ) in height and covered with thick cuticle (Fig. 12); they are polygonal to subrectangular with straight, moderately thick walls covered with smooth cuticle measuring (32-35-46 ) in length, (1316-24 ) in width (Fig. 13).

\section{The cortex}

It is formed of parenchyma cells increasing gradually in size toward the inside and containing numerous scattered clusters of calcium oxalate measuring (22-24-27 ) in diameter as well as abundant starch granules which are mostly compound and spherical with indistinct hilum and striations. The inner region of the cortex exhibits isolated groups of sclereids of various sizes and shapes; which are densely packed, with narrow lumina and very thick, striated, pitted and heavily lignified walls. The endodermis is formed of thin walled parenchyma cells containing starch granules.

The vascular system (Figs. 11 and 12)

The vascular system consists of a continuous ring of pericycle, phloem, cambium and xylem.

The pericycle is formed of nearly continuous ring of fibres interrupted by few parenchyma cells. The fibres have moderately thick, slightly lignified walls with narrow lumina. They measure (17-19-22 ) in diameter.

The phloem consists of thin-walled cellulosic elements mainly, sieve tubes, companion cells, phloem parenchyma and few phloem fibers. The phloem parenchyma contain styloids and prisms of calcium oxalate.

The cambium is formed of (3-6) rows of thin walled, subrectangular, tangentially elongated and radially arranged cellulosic cells.

The xylem consists of a comparatively wide zone of thick-walled lignified elements including xylem vessels, wood fibres and wood parenchyma. The xylem vessels which measure $(12-\underline{13}-15)$ in diameter are traversed by radially elongated subrectangular uni- to biseriate lignified medullary rays with thick pitted lignified walls containing starch granules. A wide central pith is formed of rounded parenchymatous cells. Numerous clusters of calcium oxalate as well as starch granules resemble that of the cortex are present within the cells in addition to scattered large groups of sclereids of various sizes and shapes. The sclereids are densely packed, slightly lignified, pitted, some with thick walls and narrow lumina; others with thin walls and wide lumina. 

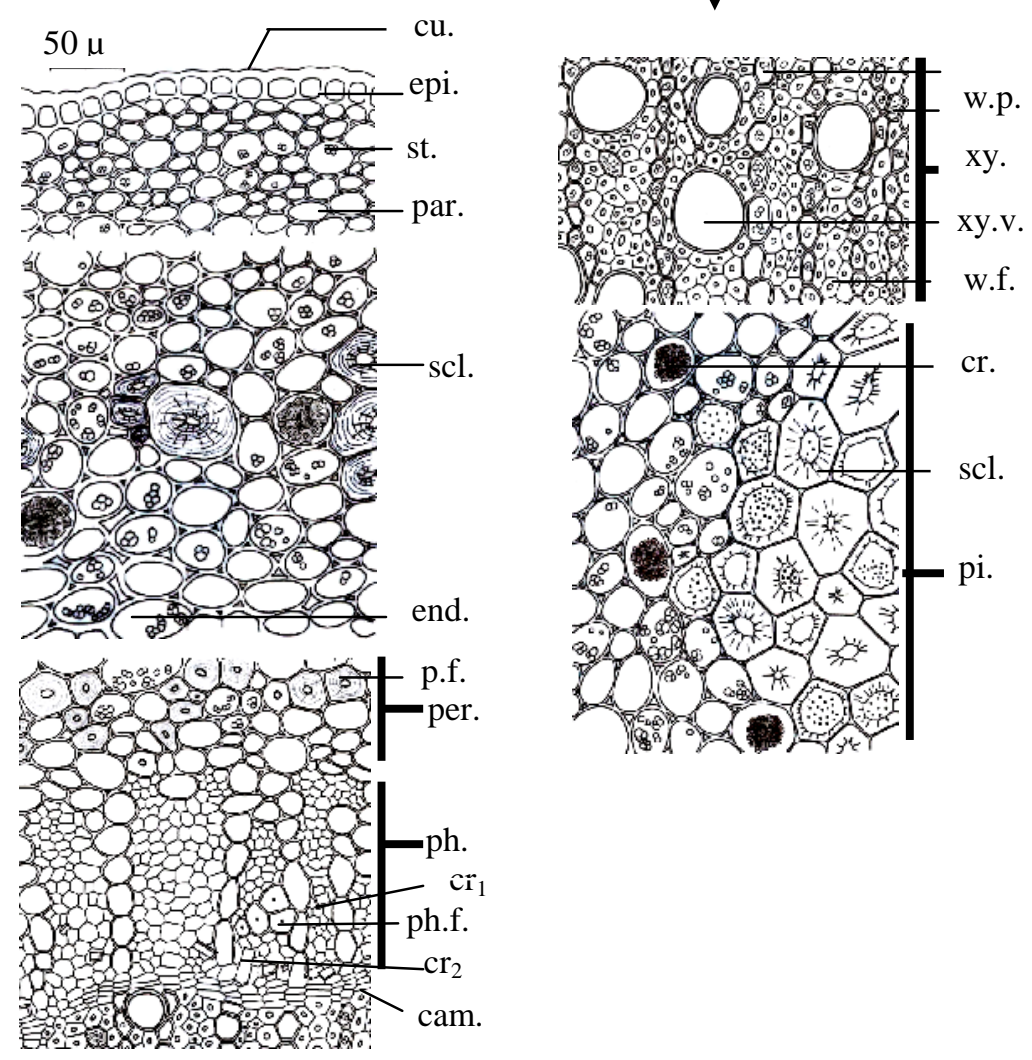

Fig. 12: The detailed T.S. of the young stem.

cam., cambium; cr., cluster of calcium oxalate; $\mathrm{cr}_{1}$, prism of calcium oxalate; $\mathrm{cr}_{2}$, styloid of calcium oxalate; cu., cuticle; end., endodermis; epi., epidermis; m.r., medullary rays; p.f., pericyclic fibres; par., parenchyma; per., pericycle; ph., phloem; ph.f., phloem fibres; pi., pith; scl., sclereids; st., starch; w.f., wood fibres; w.p., wood parenchyma; xy., xylem; xy.v., xylem vessel.

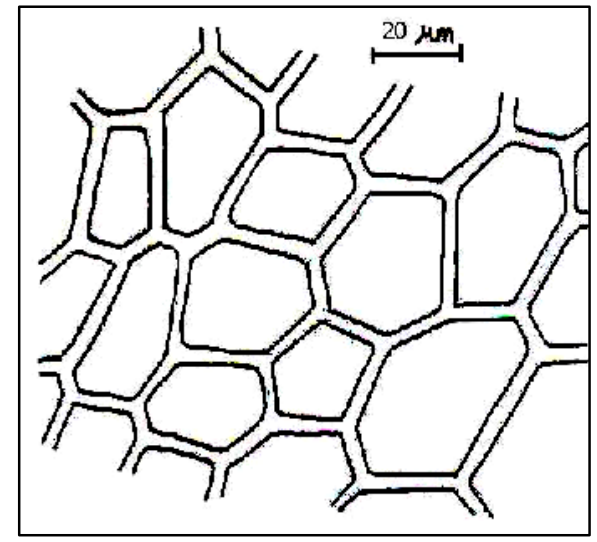

Fig. 13: The epidermis of the young stem. 
The powdered stem (Fig. 14)

Grayish green in colour, tasteless with faint odour. It is characterized by the following:

1- Scattered clusters, styloids and prisms of calcium oxalate .

2- Fragments of polygonal to subrectangular epidermal cells, having straight, moderately thick walls and covered with smooth cuticle.

3- Fragments of lignified xylem elements showing pitted, spiral and reticulate xylem vessels as well as pitted tracheids and tracheidal vessels, elongated wood fibres with narrow lumina, irregular walls and acute tapering ends measuring (14-15-17 ) in diameter and (492-500-520 ) in length in addition to pitted rectangular to sub- rectangular wood parenchyma and medullary rays containing starch granules.

4- Abundant starch granules either free or contained in parenchyma cells. They are mostly compound and spherical with indistinct hilum and striations.

5- Fragments of pericyclic fibres which have thick, slightly lignified walls with narrow lumina and blunt to rounded apices.

6- Fragments of phloem fibres which have thick slightly lignified walls with narrow lumina and tapering apices.

7- Sclereids which are single or in a densely packed groups, some are slightly lignified, others are heavily lignified, pitted, some with thick walls and narrow lumina; others with thin walls and wide lumina.

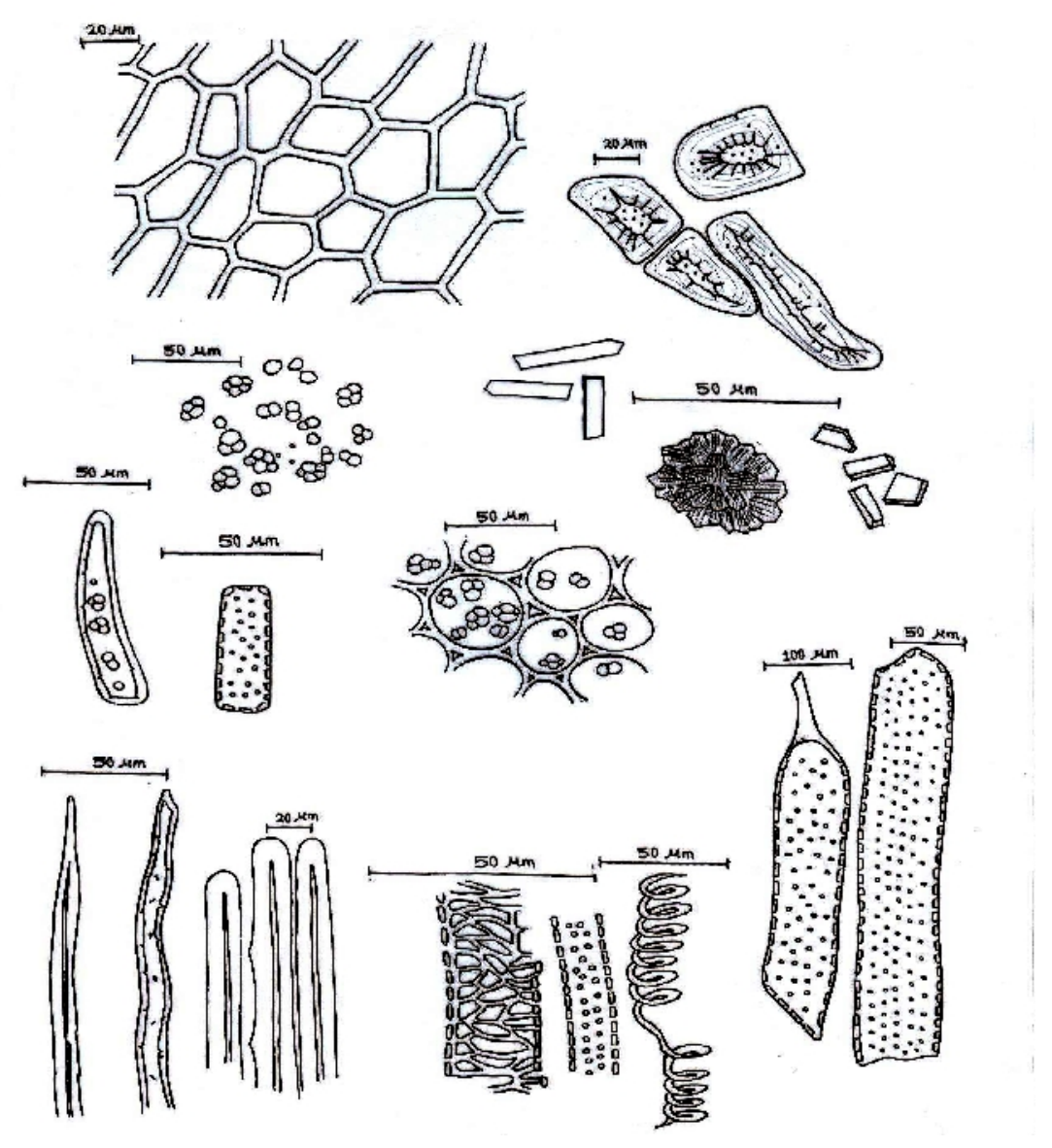

Fig. 14: Elements of the powdered stem.

cr., cluster of calcium oxalate; $\mathrm{cr}_{1}$, prisms of calcium oxalate; $\mathrm{cr}_{2}$, styloids of calcium oxalate; epi., epidermis; m.r., medullary ray; par., parenchyma containing starch; p.f. pericyclic fibres; ph.f., phloem fibres; scl. sclereids; st., starch; tr. and tr.v., tracheids and tracheidal vessels; w.f., wood fibre; w.p., wood parenchyma; xy.v., xylem vessels. 


\section{3- The stem bark}

\section{A- Macromorphology}

The inner surface of the bark has brown to reddish brown colour and is longitudinally striated. Externally it is of grayish colour and more or less rough due to presence of cracks, wrinkles or furrows (Fig. 15A and B). The fracture is short in the outer part and fibrous in the phloem region. Pieces of the bark are flat about $(5-10 \mathrm{~cm})$ in length, $(3-7 \mathrm{~cm})$ in width and $(0.5-0.8 \mathrm{~cm})$ in thickness. The bark is tasteless and has faint odour.
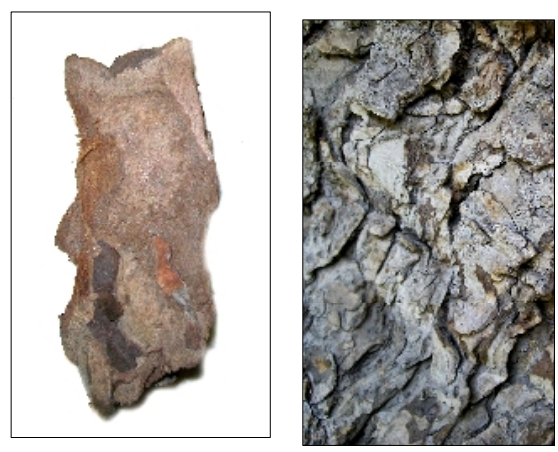

Fig. 15: Photo of the bark.
A. The outer surface.

B. The inner surface.

\section{B- Micromorphology}

The transverse section (Fig. 16), shows the following:

Cork cells, phellogen, phelloderm, pericycle and phloem traversed by medullary rays.

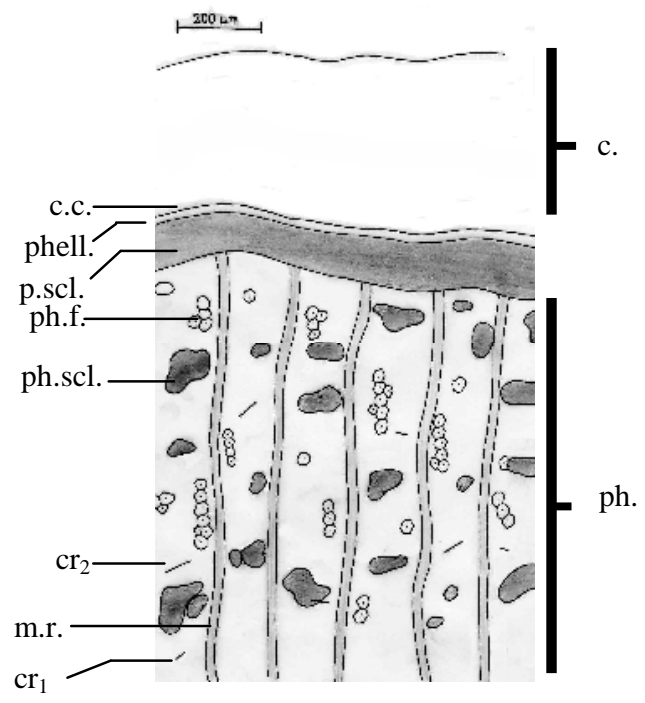

Fig. 16: The diagrammatic T.S. in the stem bark.
The cork is formed of several rows of radially arranged and tangentially elongated cells with thin, lignified walls measuring (18-25-32 ) in height (Fig. 18). They appear polygonal in shape (Fig. 20), having straight anticlinal walls measuring (40-41-45 ) in length, (26-29-32 ) in width.

The phelloderm consists of one or two rows of rounded polygonal parenchyma cells measuring (26-28-30 ) in diameter (Fig. 18).

The pericycle is composed of a continuous band of densely packed lignified sclereids, three or four cells wide, yellow in colour, pitted and striated. The cells vary in size (3035-71 ) in diameter (Fig. 18).

The phloem represents the major part of the bark and is traversed by medullary rays (Figs. 17 and 19). It is formed of sieve tubes, companion cells, phloem parenchyma, phloem fibres and sclereids. The phloem parenchyma are present in tangential bands alternating with sieve tubes, phloem fibres and sclereids (Figs. 17 and 19). They contain styloids and prisms of calcium oxalate. The phloem fibres are present in a single or in radial rows up to 10 components. Each fibre has slightly thickened, bright yellow, faintly striated lignified wall, possess a narrow lumina. They measure (580602-648 ) in length and (31-47-57) in diameter. The sclereids are rounded, polyhedral or irregular, having thick lignified walls showing striations, pits and narrow lumina (few with wide lumina). The medullary rays are uni-seriate to bi-seriate. Their cells are somewhat tangentially elongated to subrectangular filled with reddish brown pigments.

\section{The powdered bark}

The powdered bark (Fig. 20) has reddish brown colour with faint characteristic odour and almost tasteless. It is characterized by the following:

1- Very abundant scattered styloids and prisms of calcium oxalate.

2- Fragments of cork cells which are polygonal with thin lignified walls.

3- Fragments of phloem fibres either single or in groups which are large, yellow in colour, slightly lignified, with thick wall, having narrow lumina and blunt ends. 
4- Scattered sclereids with different shapes and sizes. They have thick lignified yellow walls and narrow lumina, few with wide lumina. The walls show striations and pits.
5- Fragments of medullary rays which are tangentially elongated to subrectangular filled with reddish brown pigments.

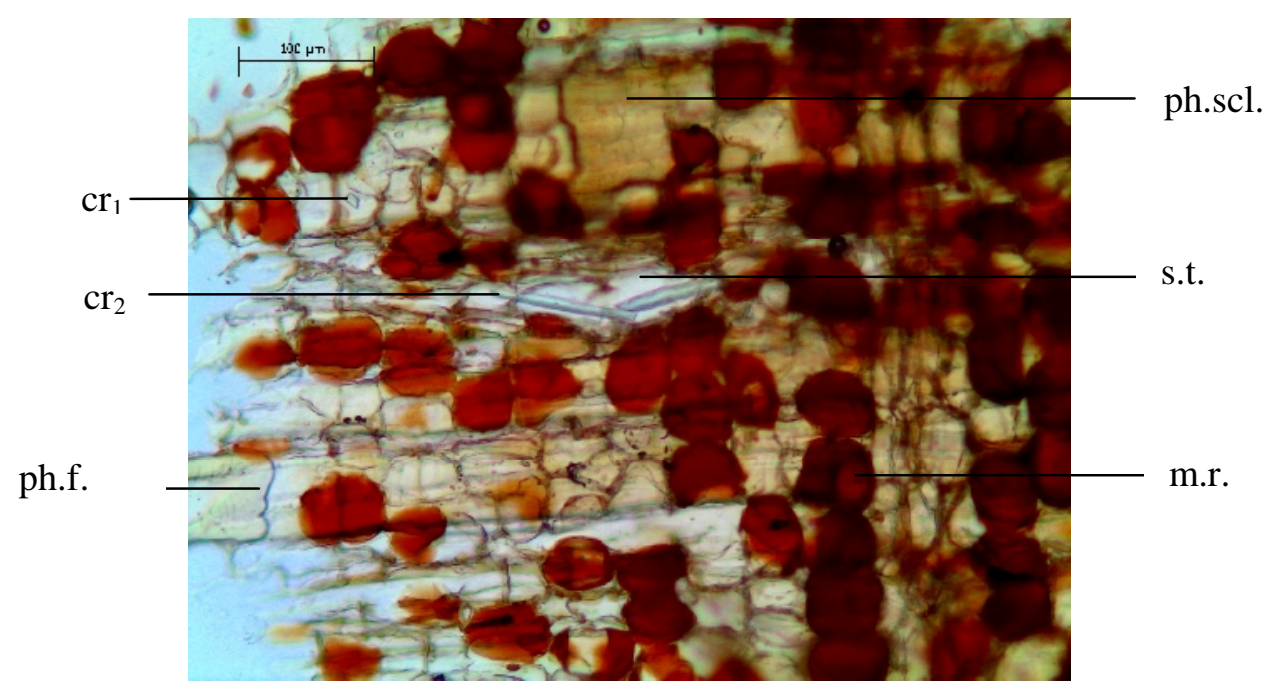

Fig. 17: Photo of the L.S. in the stem bark.

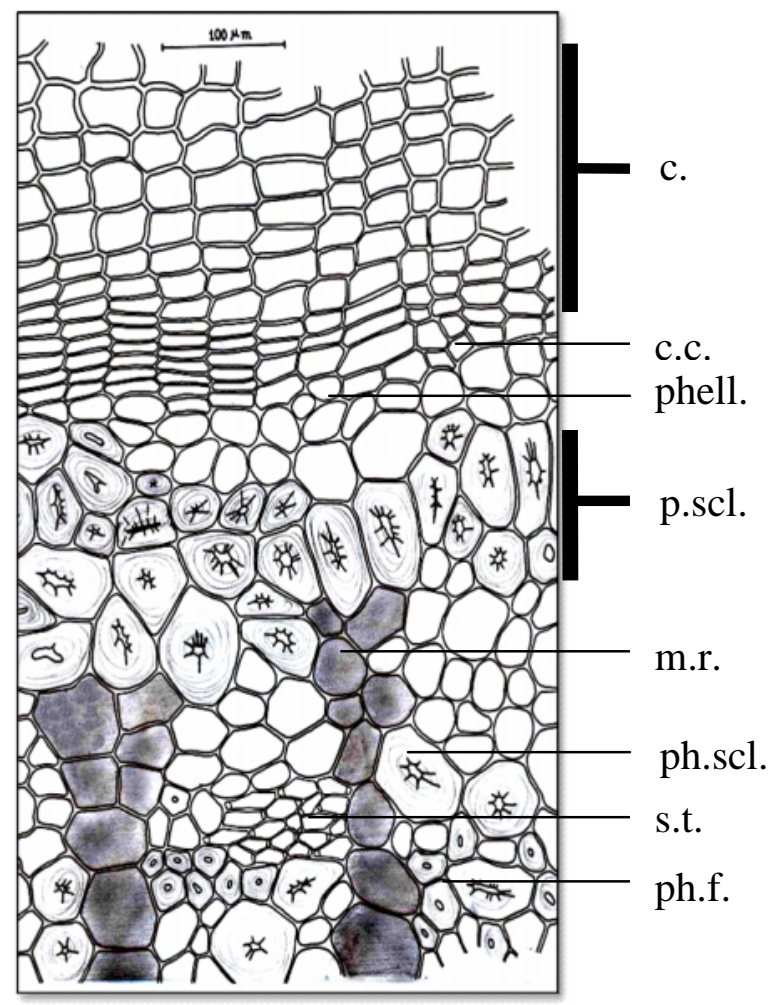

Fig. 18: The detailed T.S. in the stem bark.

c., cork; c.c., cork cambium; $\mathrm{cr}_{1}$., prism of calcium oxalate; $\mathrm{cr}_{2}$, styloid of calcium oxalate; m.r., medullary rays; p.scl., pericyclic sclereids; ph., phloem; ph.f., phloem fibres; ph.scl., phloem sclereids; phell., phelloderm. 


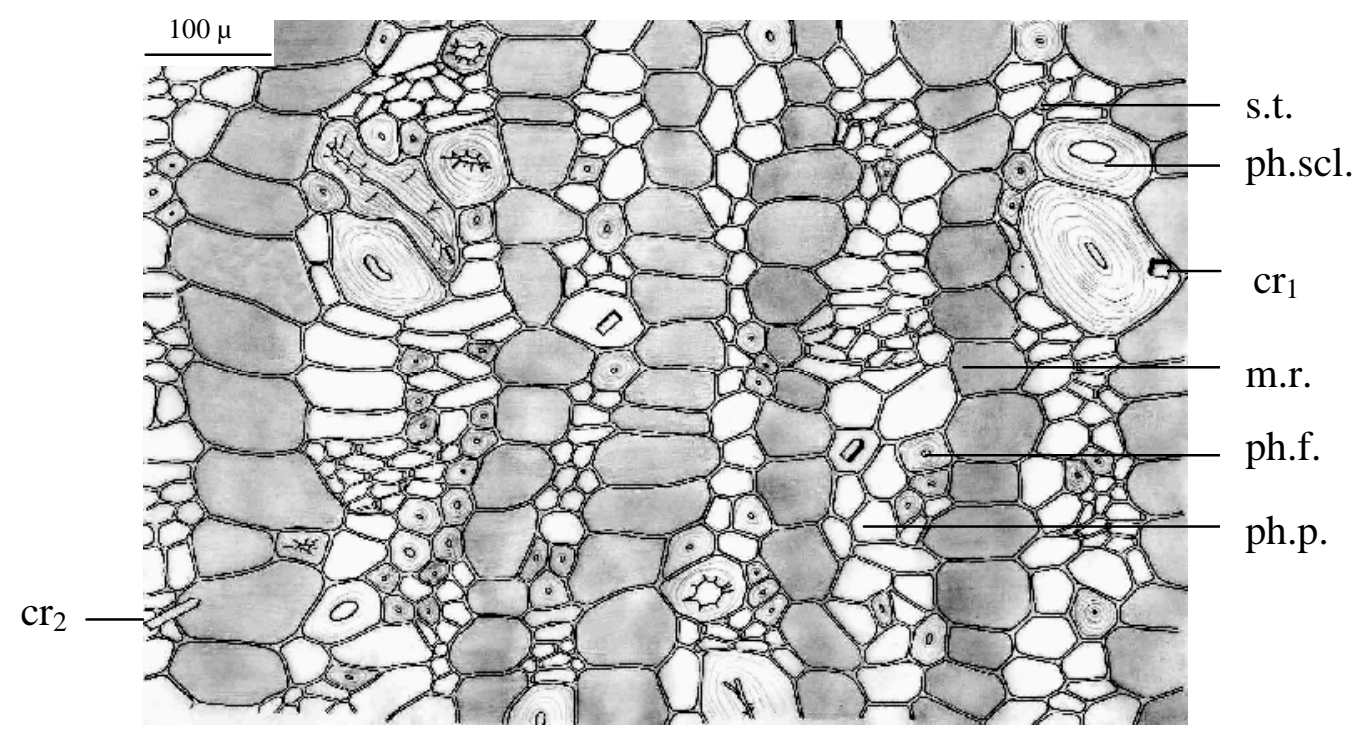

Fig. 19: The detailed T.S. in the phloem region.

$\mathrm{cr}_{1}$, prism of calcium oxalate; $\mathrm{cr}_{2}$, styloid of calcium oxalate; m.r., medullary rays; ph.f., phloem fibre; ph.p., phloem parenchyma; ph.scl., phloem sclereids; s.t., sieve tubes.

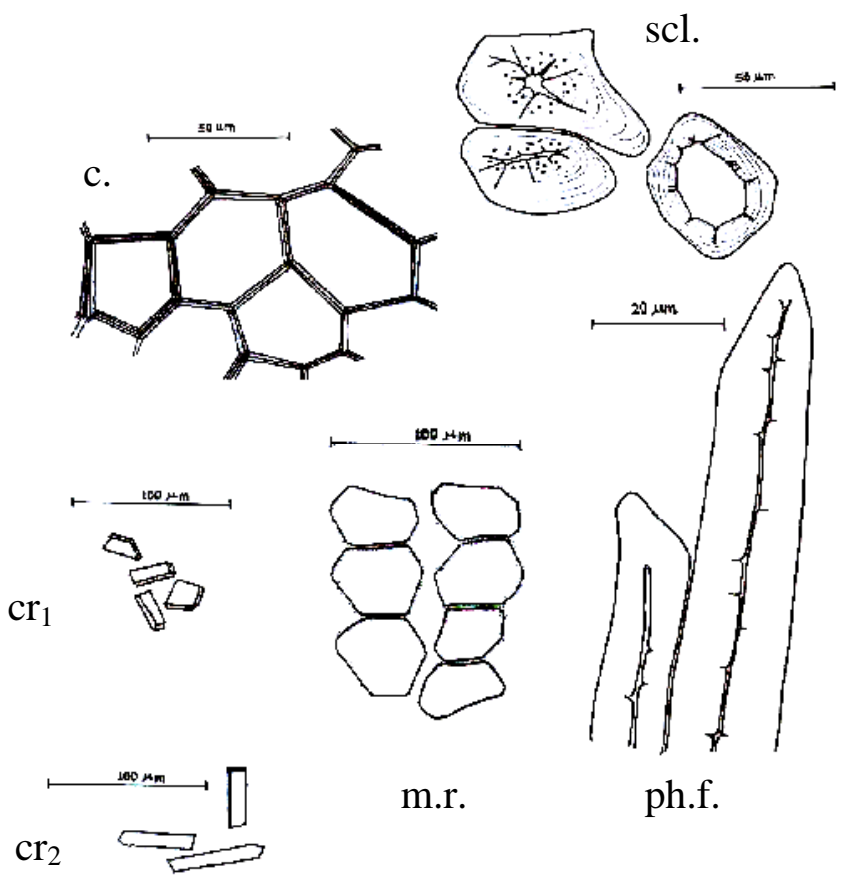

Fig. 20: Elements of the powdered stem bark.

c., cork; $\mathrm{cr}_{1}$, prisms of calcium oxalate; $\mathrm{cr}_{2}$, styloids of calcium oxalate; m.r., medullary rays; ph.f., phloem fibres; scl., sclereids. 


\section{4- The inflorescence}

\section{A- Macromorphology: (Fig. 21)}

The flowers are actually copious, peduncled, axillary dichotomous cymes. Usually borne at nodes in the axils of the leaves. Bracteoles are small present on secondary branches, usually not more than $(0.1$ $\mathrm{cm}$ ) in length. The flowers are small, bisexual measuring about $(0.5-0.8 \mathrm{~cm})$ in length, white or greenish white in colour, tasteless and have faint odour.

The bracteole is green in colour, oblong or oblong lanceolate with acute apex measuring $(0.3-0.5 \mathrm{~cm})$ in length and about $(0.1 \mathrm{~cm})$ in width.

The calyx is green in colour with 4 united sepals forming globose with 4 teeth measuring about $(0.2 \mathrm{~cm})$ in length and about $(0.1 \mathrm{~cm})$ in diameter.

The corolla is white in colour consists of 4 united petals forming a basal cylindrical corolla-tube which end in the apical part with 4 recurved ligulate lobes.

The androecium consists of 4 epipetalous stamens alternating with corolla-lobes. Anthers are oblong, 2-celled, dehiscing longitudinally while filaments are absent.

The gynaecium is inferior with bicarpellary bilocular ovary, long thick style measures about $(0.7 \mathrm{~cm})$ in length and large stigma.

The floral formula is<smiles>[Mg][Mg][Mg][Mg]</smiles>

\section{B- Micromorphology \\ The peduncle}

Transverse section is usually flattened oval in outline (Fig. 22); exhibiting a large vascular bundle surrounded by parenchymatous cortical tissue with wide central parenchymatous pith.

\section{The epidermis}

In transverse section (Fig. 23) is consists of square to subrectangular cells covered with thick cuticle measuring (19-20-23 ) in height and in (Fig. 24), they are polygonal, usually axially elongated, rarely square to subrectangular with straight, moderately thick anticlinal walls covered with smooth cuticle, measuring (32-37-40 ) in length and (11-1417 ) in width while no stomata were observed.

\section{The cortex}

The outer (2-4) rows of the cortex (Fig. 23) are formed of isolated groups of chlorenchyma cells alternating with cortical parenchyma. The rest of the cortex is formed of (8-14) rows of parenchyma cells measuring (23-25-29 ) in diameter and contain numerous clusters of calcium oxalate which measure (1417-19 ) in diameter.

The vascular system (Figs. 22 and 23)

consists of a large flattened continuous vascular cylinder of pericycle, phloem, cambium and xylem.

The pericycle is formed of scattered bundles of fibers interrupted by parenchyma. The fibers have moderately thick, slightly lignified walls with comparatively wide lumina. They measure (10-11-14 $\mu)$ in diameter.

The phloem consists of thin-walled cellulosic cells shining soft elements mainly of sieve tissue, companion cells and phloem parenchyma traversed by medullary rays.

The cambium is formed of (2-3) rows of thinwalled, subrectangular, tangentially elongated and radially arranged cellulosic cells.

The xylem consists of a narrow zone of thickwalled lignified elements include xylem vessels, wood fibres and wood parenchyma. The xylem vessels are arranged in radial rows traversed by uni- or bi-seriate, thin, lignified, radially elongated subrectangular medullary rays measuring (9-11-15 ) in diameter and containing brown content. The wood fibers are rare; measuring (8-10-12 ) in diameter.

The pith is a wide central zone of rounded to oval parenchymatous cells; containing clusters of calcium oxalate with isolated groups of pitted lignified sclereids. 


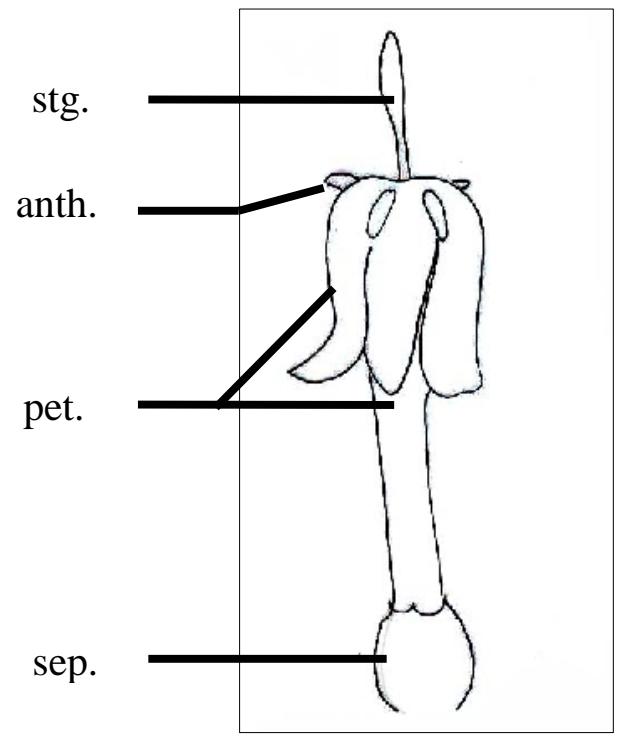

Fig. 21: Close up of the flower

anth., anther; pet., petals; sep., sepals; stg., stigma.

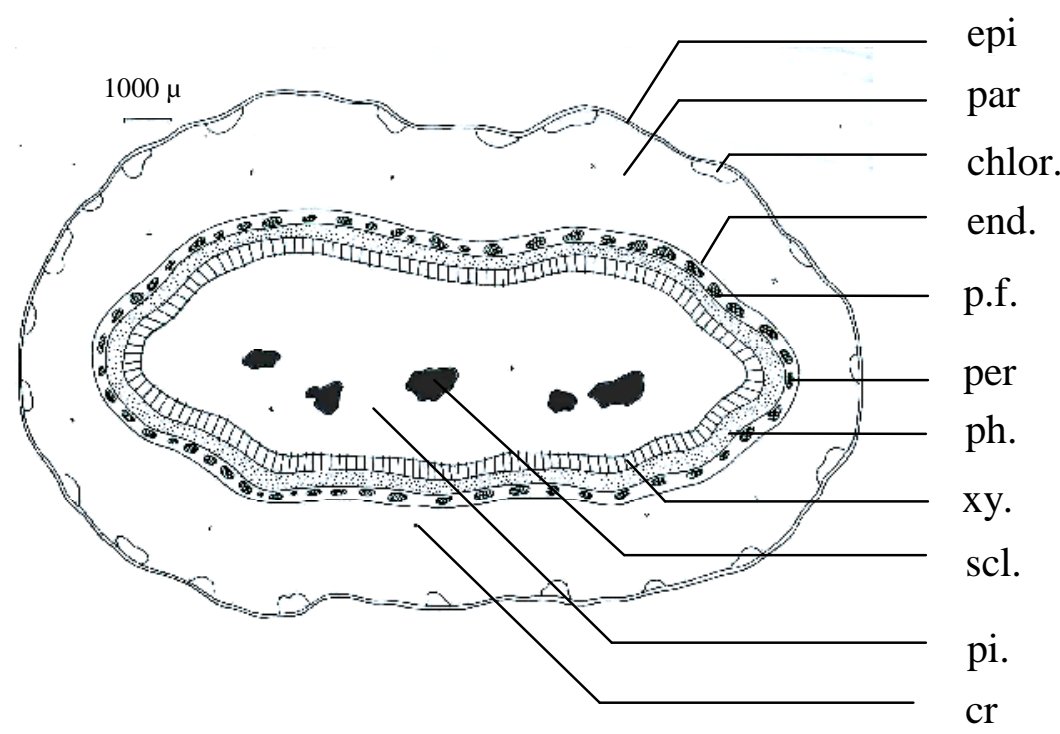

Fig. 22: The diagrammatic T.S. in the peduncle.

chlor., chlorenchyma; cr., cluster of calcium oxalate; end., endodermis; epi., epidermis; p.f., pericyclic fibres; par., parenchyma; per., pericycle; ph., phloem; pi., pith; scl., sclereids; xy., xylem. 


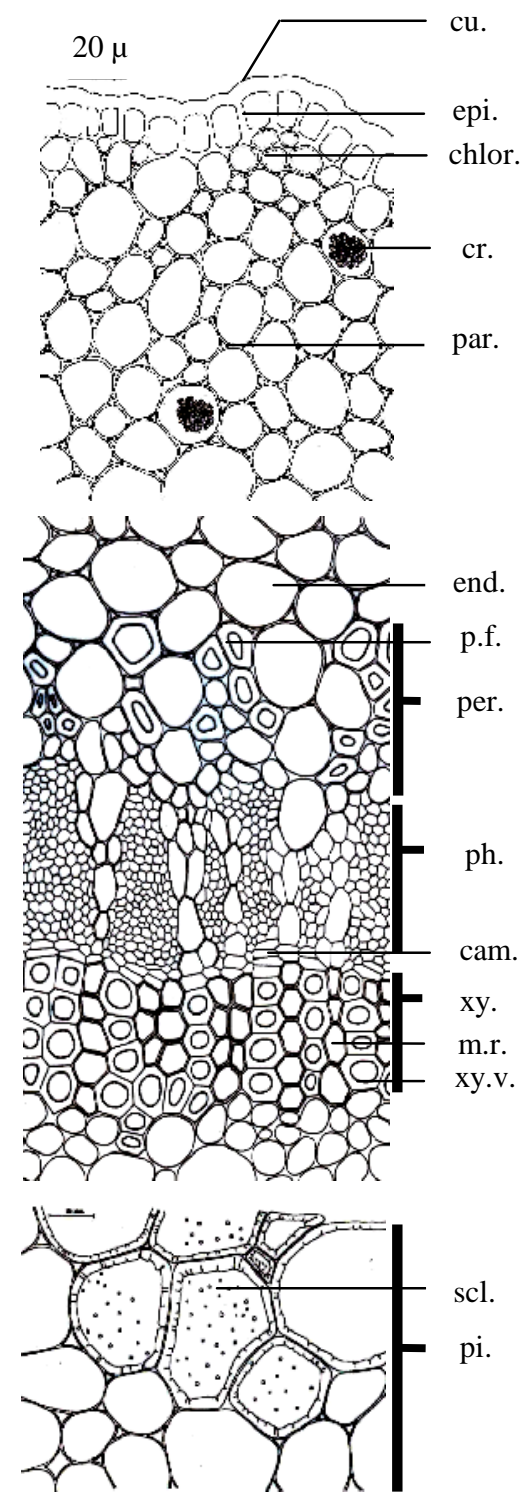

Fig. 23: The detailed T.S. in the peduncle.

cam., cambium; chlor., chlorenchyma; cr., cluster of calcium oxalate; cu., cuticle; end., endodermis; epi., epidermis; m.r., medullary rays; p.f., pericyclic fibres; par., parenchyma; per., pericycle; ph., phloem; pi., pith; scl., sclereids; xy., xylem; xy.v., xylem vessel.

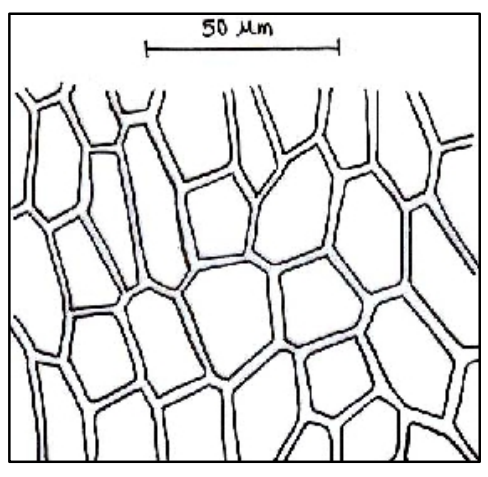

Fig. 24: The epidermis of the peduncle. 


\section{The powdered peduncle}

The powdered peduncle (Fig. 25) is yellowish brown in colour with faint odour and almost tasteless. It is characterized by the following:

1- Fragments of epidermal cells with straight, moderately thick anticlinal walls covered with smooth cuticle.

2- Numerous xylem fragments showing pitted, scalariform and spiral lignified xylem vessels as well as tracheidal vessels which have blunt ends with lignified scalariform thickening, they measure (11-15-18) in width and lignified wood fibres with thick irregular pitted walls, narrow lumina and acute tapering ends measuring (190-204-218 ) in length.

3- Fragments of pericyclic fibres which have moderately thick, slightly lignified walls with comparatively wide lumina and blunt apices. Few of them have dentate wall.

4- Fragments of lignified, pitted rectangular to subrectangular wood parenchyma with wide lumina measuring (120-128-140 ) in length and (23- $\underline{25}-28$ ) in width.

5- Numerous scattered clusters of calcium oxalate.

6- Fragments of lignified, pitted sclereids from the pith.

7- Fragment of medullary rays which are radially elongated subrectangular cells with thin lignified walls and containing brown content.

\section{The powdered flower}

The powdered flower (Fig. 26) is yellowish brown in colour with faint characteristic odour and almost tasteless. It is characterized by the following:

1- Numerous non glandular hairs appear on the surface of the lower part of the style, mainly of the unicellular type, conical in shape, with thin walls and acute apices covered with smooth cuticle. They measure (190$\underline{195}-198$ ) in length and (16- $\underline{18}-20$ ) in width.

2- Numerous pollen grains, which are spherical with warty or strongly beaded exines having three germ pores and three furrows. They measure (16-18-20 ) in diameter.

3- Fragments of the outer epidermis of the corolla, which are longitudinally elongated with slightly sinuous thin walls covered with faintly striated cuticle. They measure (32-34-36 ) in length and (12-14-16 ) in width.

4- Fragments of the inner epidermis of the corolla, which consists of polygonal cells with nearly straight thin walls covered with smooth cuticle measuring (23-25-28 ) in length and (17-19-23 ) in width.

5- Fragments of the outer epidermis of the calyx, which are polygonal cells with straight, thick walls covered with smooth cuticle. They measure (11- $12-15$ ) in length and (8-9-11 ) in width.

6- Fragments of the inner epidermis of the calyx, which are polygonal cells with granular contents and moderately thick walls covered with smooth cuticle. They measure (11- $\underline{-13}-15$ ) in length and (8- $\underline{10}-12$ ) in width.

7- Fragments of the epidermal cells of the style, which are rectangular to subrectangular, axially elongated with straight thick anticlinal walls. They measure (42-44-46 ) in length and (11-13-15 ) in width carrying non glandular hairs.

8- Abundant fragments of the fibrous layer of anthers which are elongated cells show characteristic thickening and beaded walls.

9- Lignified spiral xylem vessels and small tracheids. 


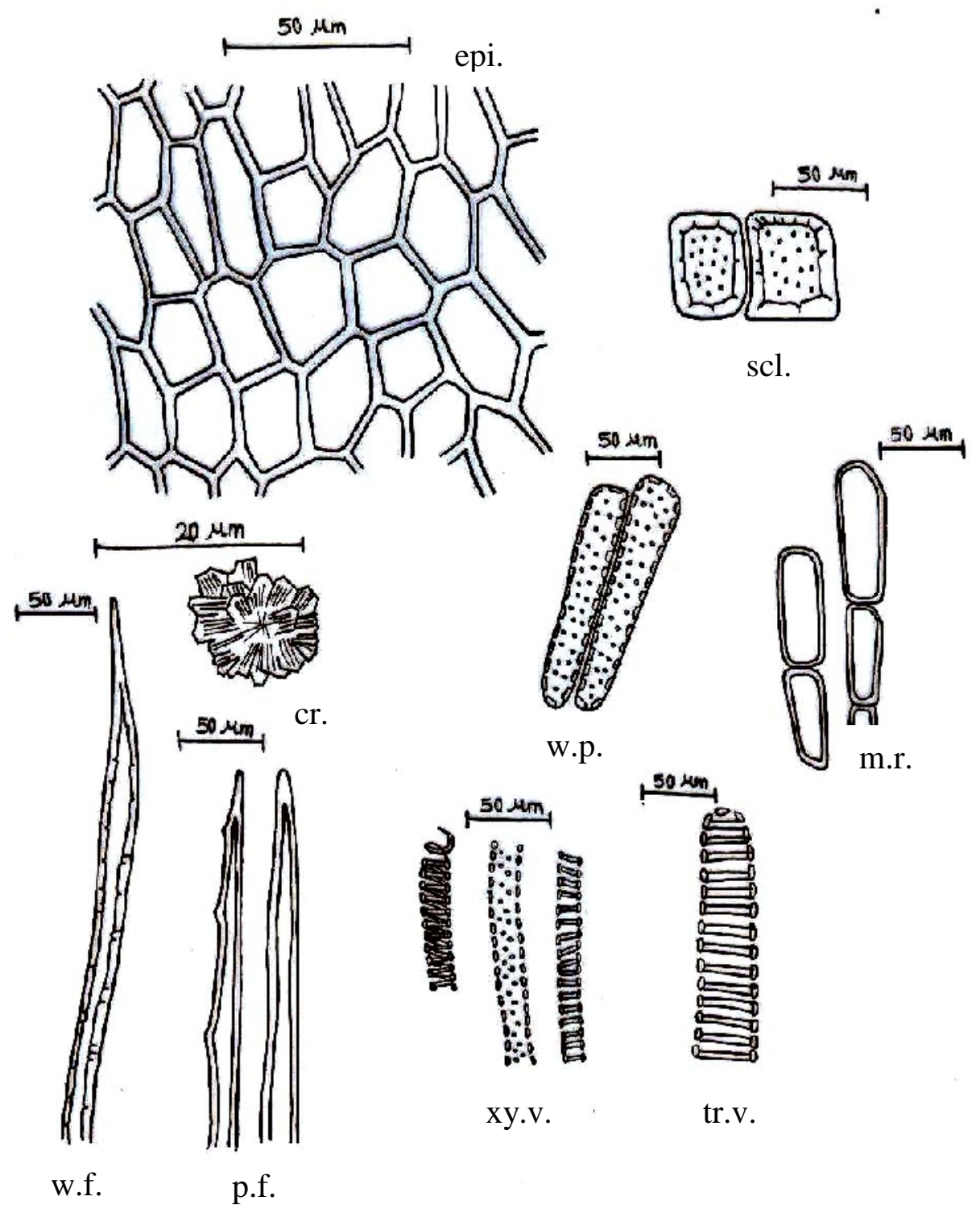

Fig. 25: Elements of the powdered peduncle.

cr., cluster of calcium oxalate; epi., epidermis; m.r., medullary rays; p.f. pericyclic fibres; scl. sclereids; tr.v., tracheidal vessels; w.p., wood parenchyma; w.f., wood fibres; xy.v., xylem vessels. 


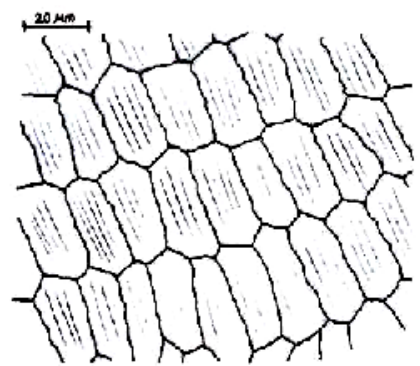

o.epi.co.

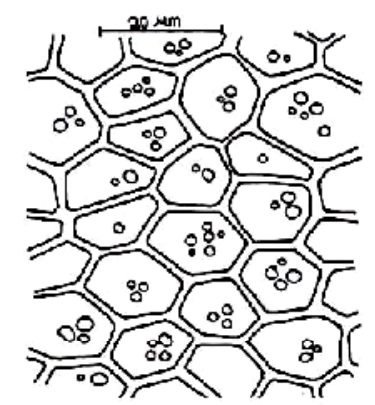

i.epi.ca.

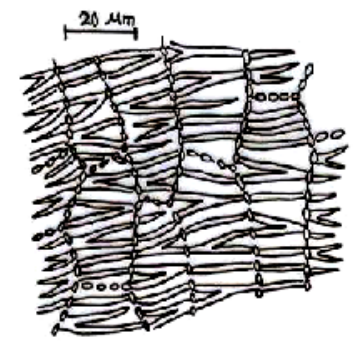

fib.l.anth.

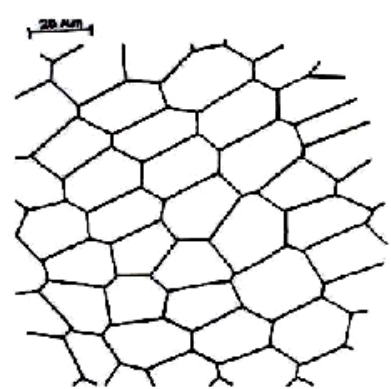

i.epi.co.

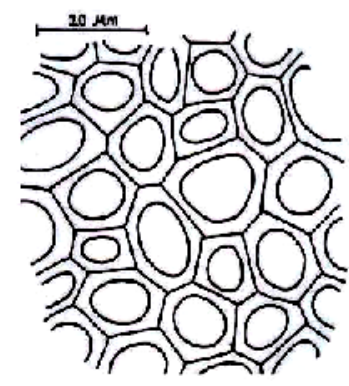

o.epi.ca.

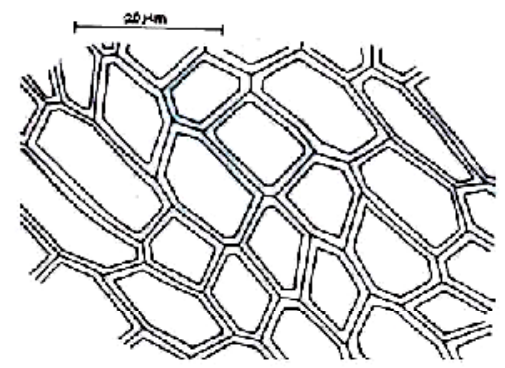

epi.sty.

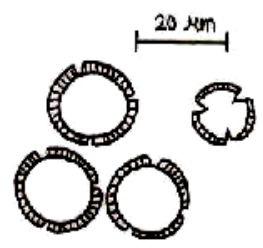

p.g.

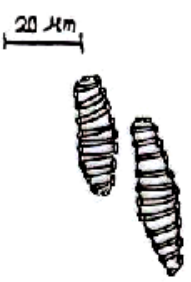

tr.

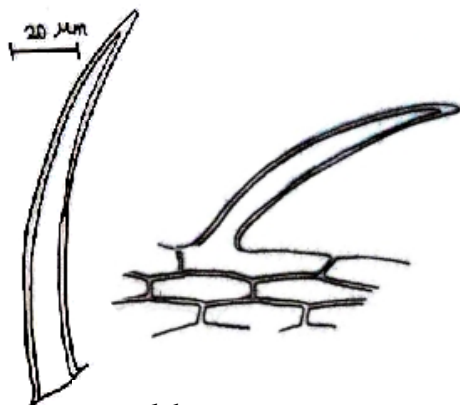

n.gl.h.

Fig. 26: Elements of the powdered flower.

$$
\text { xy.v. }
$$

epi.sty, epidermis of style; fib.l.anth., fibrous layer of anther; i.epi.ca., inner epidermis of the calyx; i.epi.co., inner epidermis of the corolla; n.gl.h., non glandular hair from the style; o.epi.ca., outer epidermis of the calyx; o.epi.co., outer epidermis of the corolla; p.g., pollen grains; tr., tracheids; xy.v., xylem vessels.

\section{Conclusion}

From this study, we can concluded that:

The most important macro- and micromorphological characters of this plant include:

1- Shortly petiolated, simple, very large, glabrous, elliptic-ovate leaves, with acuminate apices and entire margins.

2- Copious, peduncled, axillary dichotomous cymes in the axils of the leaves.
3- Brown to reddish brown, longitudinally striated inner surface and gray and rough outer surface of the bark.

4- Glabrous upper and lower epidermises of the leaf with non lignified sclerenchymatous cells and paracytic stomata in the lower epidermis.

5- Subrectangular medullary rays filled with reddish brown pigments. 


\section{REFERENCES}

1- C. R. Metcalfe and L. Chalk, "Anatomy of the Dicotyledons". Clarendon press, Oxford, $2^{\text {nd }} E d, 1972$, pp.759-761.

2- G. Castillo-Campos and H. Ochoterena, "Rubiaceae diversity in the state of Veracruz, Mexico", IV International Rubiaceae (Gentianales) Conference. Meise National Botanic Garden (Belgium), 44, 8 (2008).

3- G. H. M. Lawrence, "Taxonomy of vascular plants". Macmillan company, New York. $12^{\text {th }}$ printing, 1968, pp.712713.
4- F. Lens, S. Jansen, E. Robbrecht and E. Smets, "Wood anatomy of the Vanguerieae (Ixoroideae-Rubiaceae), with special emphasis on some geofrutices", Iawa Journal, 21 (4), 443-455 (2000).

5- H. j. de Boer, A. Kool, A. Broberg, W. R. Mziray, I. Hedberg and J. J. Levenfors "Anti-fungal and anti-bacterial activity of some herbal remedies from Tanzania". J. Ethnopharmacol., 96, 461-469 (2005).

6- J. H. Wiersema and B. Leo"n, "World economic plants: A standard reference". CRC press LLC, USA, 1999, pp.517-518. 